Luljeta Pinguli, Xhaklina Cani, Ilirjan Malollari,
Dhurata Premti

University of Tirana, Faculty of Natural Sciences, Department of Industrial Chemistry, Blv "Zogu I", Tirana, Albania
Scientific paper

ISSN 0351-9465, E-ISSN 2466-2585

UDC:663.42.001.7

doi:10.5937/zasmat1804507P

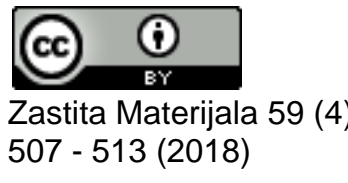

\title{
Advantages of using chlorine dioxide in brewing industry
}

\begin{abstract}
In a brewery it is very important to ensure hygienic conditions. Chlorine dioxide is a multispectral disinfectant that is more powerful, easier to use, and more environmentally friendly than chlorine. Usage of chlorine dioxide in a brewery has a lot of advantages because it can be used in different places for different purposes. Chlorine dioxide is able to penetrate, disrupt and destroy the biofilm where chlorine is completely ineffective. The main applications include, cleaning in place process $(C I P)$ and sanitizing operations. It is noticed that chlorine dioxide is very effective especially when it is used as the final sanitizing rinse agent in CIP systems. The second application most important is to control biofilms found randomly on heat exchange surfaces, in pipes, lines, orifices pumps, conveyors, chains etc. In the form of spray solution can be used as a manual sanitizing agent for different surfaces such as for example, filler head assemblies during filling process. $A$ very important application is at water filtration and distribution system disinfection. Chlorine dioxide is very effective when it is used for water disinfection both used for drinking and housekeeping. Ambient hygiene control especially in filling line is very important. Misting of chlorine dioxide solutions into air streams prevents the spread of mould and wild yeast. Chlorine dioxide is also an excellent odor neutralizer, helping to control mould and odor control. This process controls "off-tastes" in the final product. Chlorine dioxide solutions are also very effective for sanitizing and removing biofilms from the internal surfaces of transportation vessels. In order to have optimal results it is needed a careful study, because for each application the range of concentration and contact time is different. On the other hand it is very important to control his corrosive properties.
\end{abstract}

Keywords: chlorine dioxide, sanitizing agent, biofilm, corrosion.

\section{INTRODUCTION}

In a brewery it is very important to ensure hygienic conditions. This objective should be achieved with minimal work, water and energy costs. In the same time sanitation process must be safe for operators, environment and equipments too. There are a lot of disinfectants used in a brewery, such as chlorine and hypochlorite that are used for different purposes such as cleaning, sanitizing, to destroy biofilms, eliminates odors etc. Chlorine and chlorine dioxide are both oxidizing agents (electron receivers). The selectivity and oxidation potential

\footnotetext{
${ }^{*}$ Corresponding author: Luljeta Pinguli

E-mail: luljeta.pinguli@fshn.edu.al

Paper received: 22. 09. 2018.

Paper accepted: 19. 10. 2018.

Paper is available on the website: www.idk.org.rs/journal
}

makes $\mathrm{ClO}_{2}$ a desirable alternative to free chlorine. Its biocide efficiency is equal to or superior to chlorine. However, chlorine has the capacity to take in two electrons, whereas chlorine dioxide can absorb five. Moreover, $\mathrm{ClO}_{2}$ is effective over a wide $\mathrm{pH}$ range and is very effective for removing iron and manganese. This means that, mole for mole, $\mathrm{ClO}_{2}$ is 2.5 times more effective than chlorine. Chlorine dioxide works quickly and breaks down into inert compounds. Its unique chemistry produces no toxic organic chlorine by-products (such as THM's) and is therefore an environmentally friendly alternative to traditional sanitizers. Chlorine dioxide is also a very efficient, proven virucide and fungicide and is effective in destroying detrimental wild yeast strains [1].

Chlorine dioxide is generally accepted to be, more powerful, easier to use, and more environmentally friendly than equivalent chlorine treatments. It is a more expensive treatment, but its superior environmental performance means that it 
is rapidly replacing chlorine in a number of applications [2].

This paper aims to investigate chlorine dioxide as a hygiene controller in a brewery. As a multispectral disinfectant and eco friendly one comparing to other traditional disinfectants used in a brewery, to explore different applications inside the brewery and their optimal dosage to ensure satisfying hygiene control.

\section{EXPERIMENTAL PART}

Nearly all brewery equipment including tanks, fermenters, brew kettles, and lauter tuns are made of stainless steel. Most brewery equipment is constructed from Type 304 stainless steel, which has good corrosion resistance properties. At "Stefani \& Co" brewery there is a Clean-in-Place system for cleaning. There are two types of cleaning detergent used in the brewery: alkaline-based or acid-based detergents that are often formulated with surfactants, chelating agents, and emulsifiers to enhance the effectiveness of the detergents.

Sodium hydroxide, commonly used in the CIP systems of commercial breweries, is quite effective for removing organic deposits from stainless surfaces. As acid detergent is used phosphoric acid especially for the removal of beerstone and similar deposits on surfaces such as protein material resins and yeasts. There were performed tests in industrial and experimental scale. In experimental scale were tested corrosive properties of chlorine dioxide and disinfection kinetics versus contact time, $\mathrm{pH}$ and concentration.
Chlorine dioxide was used also in different applications inside the brewery in industrial scale. The main applications are listed below:

- Housekeeping and maintenance procedures in the brewery. Manual sanitizing processes.

- Final rinsing additive in CIP system.

- Manual sanitizing agent at filling line heads.

- Sanitizing agent of different packaging materials (cans, PET).

- Ambient odor and air quality control (especially at filling lines environment and microbiologic laboratory).

- Supply water disinfection.

- Waste water treatment.

- Different housekeeping procedures, especially to control biofilms in conveyors, transport equipments etc.

Analytical and microbiologic tests carried out were standard methods from European Brewery Convention, "Analytica and Microbiologica EBC" [35].

\section{RESULTS AND DISCUSSION}

As described in experimental part there were done a lot of applications in experimental and industrial scale. In this paper we are representing only some of our observations.

\section{Study of chlorine dioxide disinfection kinetics}

To study killing microorganisms kinetics versus temperature, contact time and $\mathrm{ClO}_{2}$ was used the apparatus showed in figure 1 .
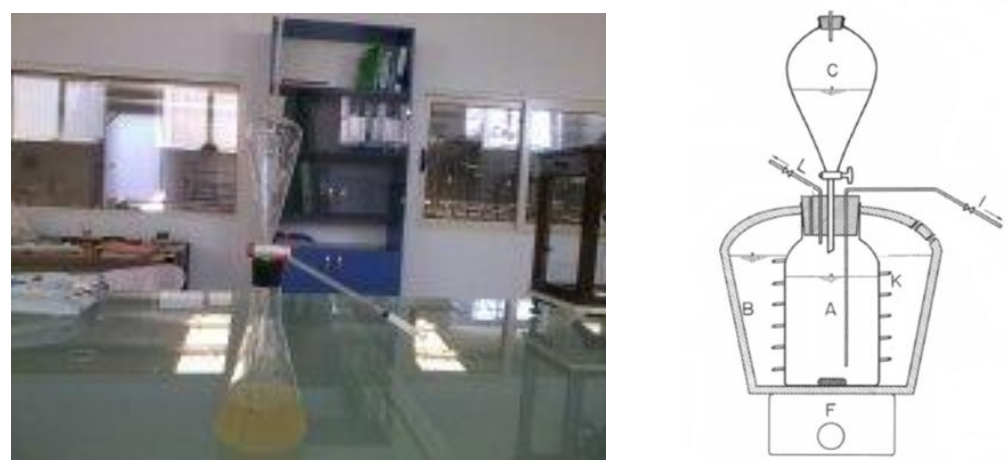

Figure 1. Apparatus build to study disinfection kinetics of $\mathrm{ClO}_{2}$

Slika 1. Aparati za proučavanje kinetike dezinfekcije sa $\mathrm{ClO}_{2}$

Killing kinetics is proportional with contact time and temperature. For wastewater treatment it is recommended to use a $\mathrm{ClO}_{2}$ concentration up to 5 $\mathrm{mg} / \mathrm{l}$. If we suppose that we have a pseudohomogeny medium, kinetics will be [6]:

$$
-\frac{1}{V} \frac{d V_{C}}{d t}=k c
$$

If we suppose that volume is constant and we are in batch conditions equation will be:

$$
-\frac{d c}{d t}=k c \quad \text { or for upper rates } \quad-\frac{d c}{d t}=k c^{n}
$$

If we suppose that we will take in continuous samples from the apparatus, than volume is a function of time and equation will be: 


$$
-\frac{d c}{d t}=k c^{n} V-\frac{d V}{d t} c
$$

Analogues to "Chick" low, equation 2 for batch conditions will transform in:

$$
-\frac{d N}{d t}=k N^{n}
$$

Where, $\mathrm{N}$ is number of cells in the system that survey from disinfection procedure. Equation 3 if volume changes will time will transform:

$$
-\frac{d N}{d t}=k^{l} N^{n}-\frac{d \ln V}{D T} N
$$

Disinfection kinetics is represented by the product CxT. This parameter determines the effectiveness of a disinfectant to kill $99 \%$ of microorganisms. This parameter represent the time $\mathrm{T}$ that it is needed for a given concentration to kill $99 \%$ of microorganisms. Higher this value, better the performance of disinfectant.

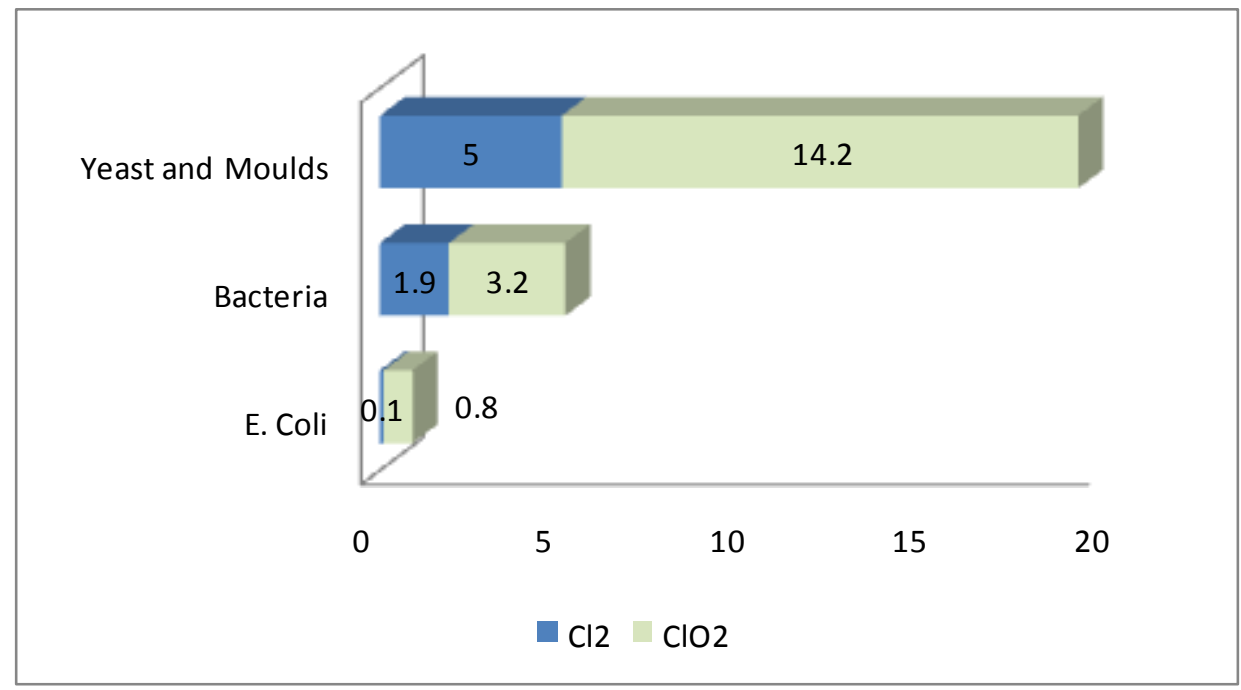

Figure 2. CxT value for chlorine and chlorine dioxide used in the treatment of waste waters produced by the brewery

Slika 2. CxT vrednost za hlor i hlor dioksid koji se koriste u tretmanu otpadnih voda proizvedenih od strane pivare

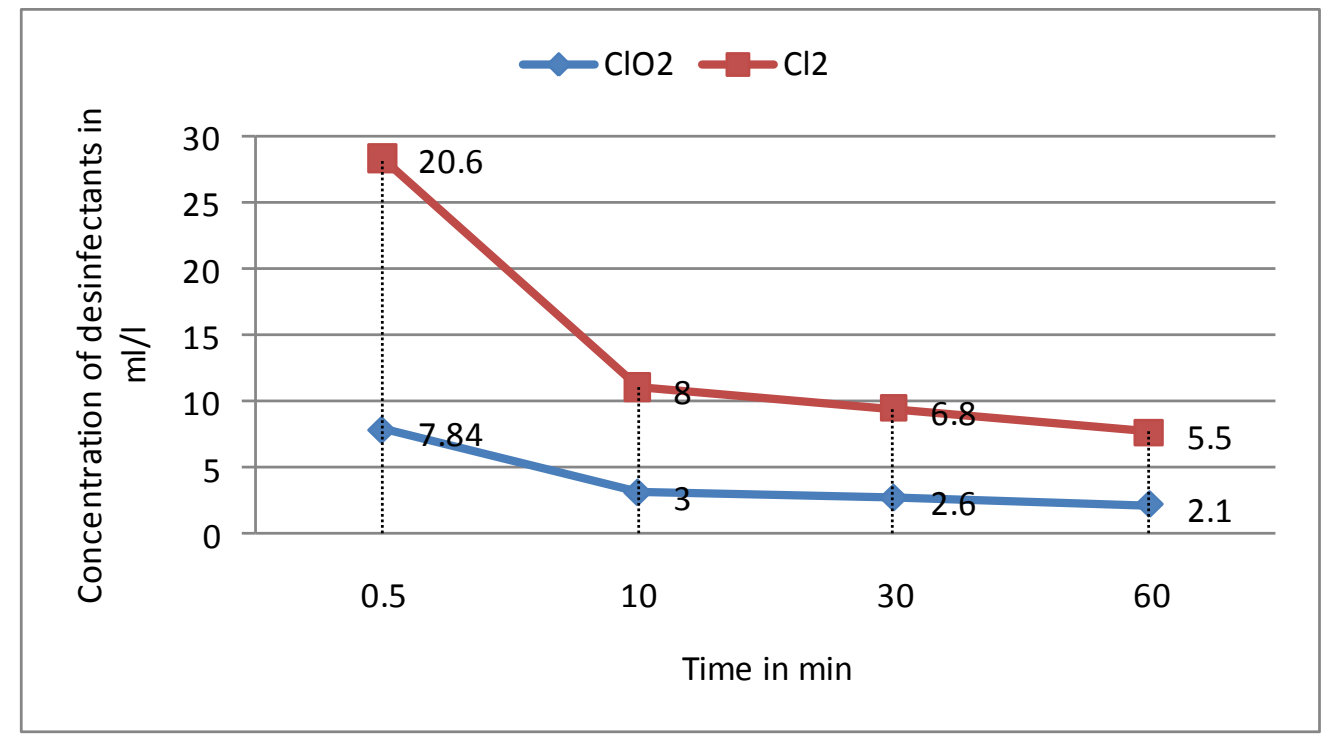

Figure 3. Impact of contact time in effectiveness of disinfectant to kill 99\% of microorganisms

Slika 3. Uticaj vremena kontakta na efikasnost dezinfekcionog sredstva za uklanjanje 99\% mikroorganizama 

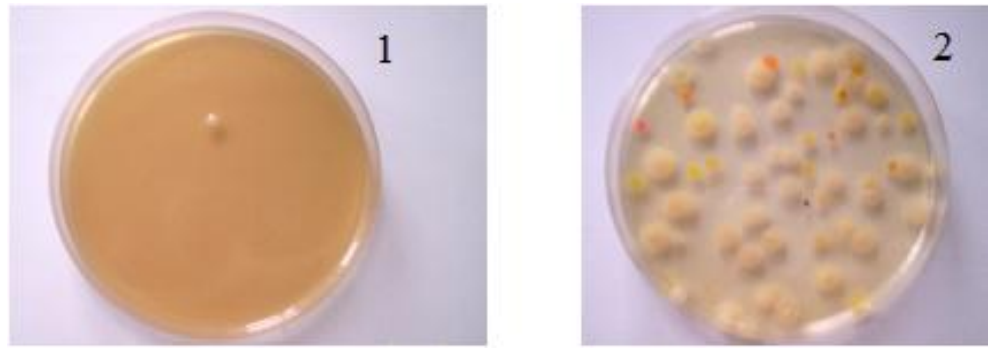

Figure 4. Bacterial loading after waste water treatment with $1 \mathrm{mg} / \mathrm{l} \mathrm{ClO}$ (fig 1) compared to non treated water (figure 2)

Slika 4. Bakterijska opterecenja nakon tretmana otpadnih voda sa $1 \mathrm{mg} / \mathrm{l} \mathrm{ClO}_{2}$ (slika 1) u poređenju sa neprerađenom vodom (slika 2)

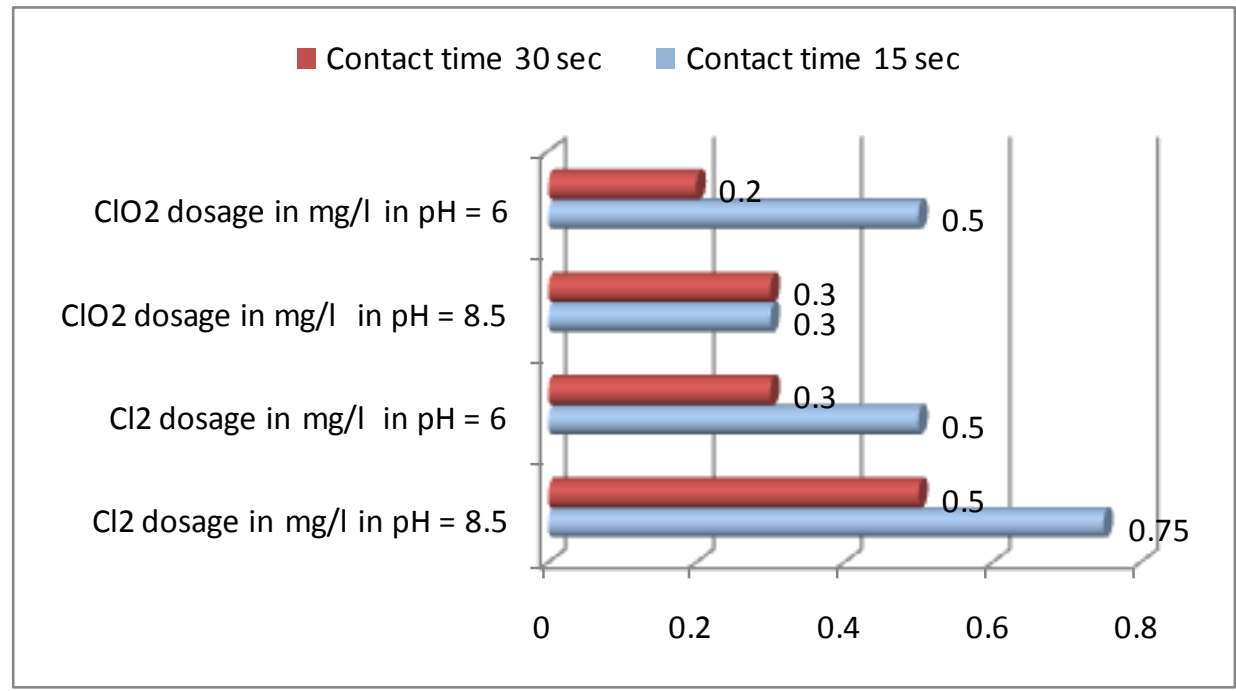

Figure 5. Dosage of $\mathrm{Cl}_{2}$ and $\mathrm{ClO}_{2}$ in $\mathrm{pH}=8.5$ and $\mathrm{pH}=6$ to kill $99 \%$ of microorganisms in drinking water for two different contact times.

Slika 5. Doziranje $\mathrm{Cl}_{2}$ i $\mathrm{ClO}_{2}$ pri $\mathrm{pH}=8.5 \mathrm{i} \mathrm{pH}=6$ u cilju uklanjanja 99\% mikroorganizama u pitkoj vodi za dva različita vremena kontakta

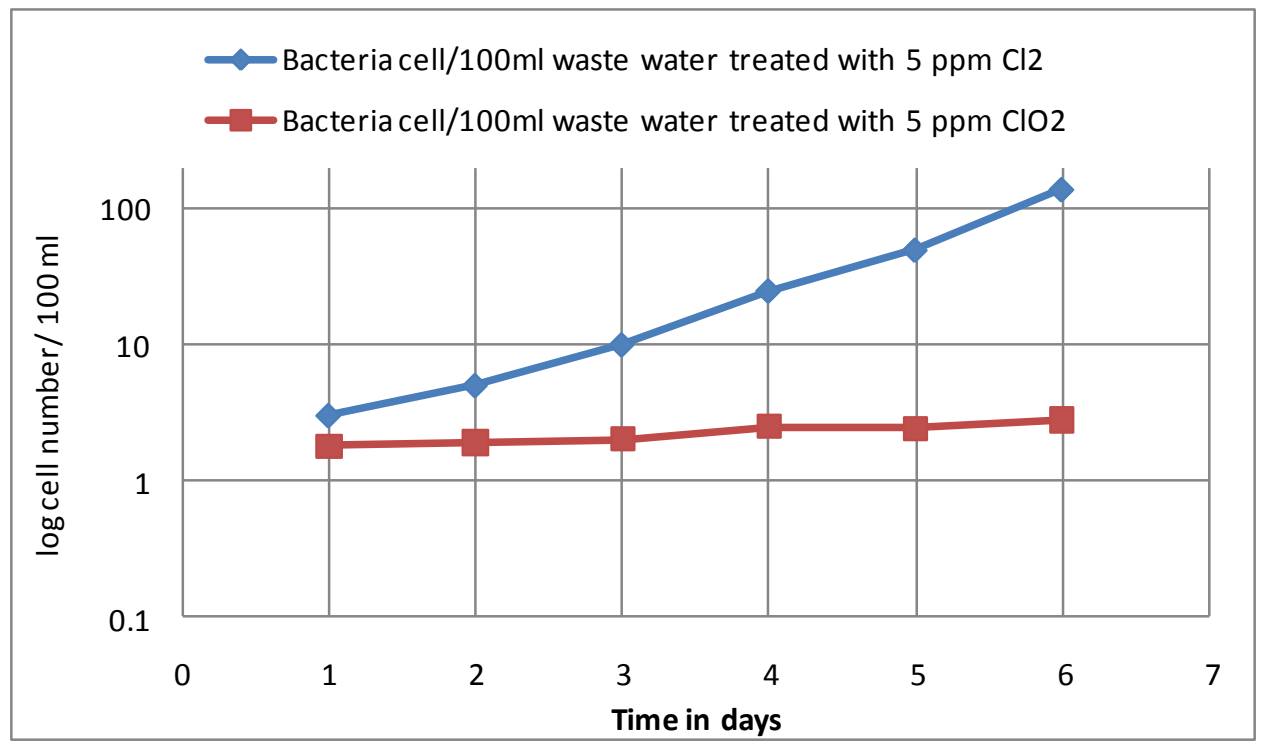

Figure 6. Bacterial growth after waste water disinfection with chlorine and chlorine dioxide Slika 6. Rast bakterija nakon dezinfekcije otpadnih voda sa hlorom i hlor dioksidom 
"Bacterial Growth" is a phenomena that explains how fast microbial population grow after sterilization or sanitizing process. After using chlorine, waste waters bacterial population grow relatively fast. In the same conditions using chlorine dioxide this growth is slower.

\section{Usage of Chlorine dioxide as sanitizing agent for} packaging materials instead of peracetic acid.

Packaging materials used for these trials were PET, bottles and cans. These packaging materials were treated with a rinsing stream of water with different concentration of sanitizing agent: $0.5 \mathrm{mg} / \mathrm{l}$, $0.75 \mathrm{mg} / \mathrm{l}, 1 \mathrm{mg} / \mathrm{l}, 2 \mathrm{mg} / \mathrm{l} \mathrm{ClO}{ }_{2}$ and peracetic acid. After 5 hours we take samples to evaluate microbiologic loading in two different mediums; wort agar (WA) and plate count agar medium (PCA).

Best results were taken when chlorine dioxide were up to $1 \mathrm{mg} / \mathrm{l}$. These results were the same and in some cases better than paracetic acid sanitizing procedure.

\section{Impact of chlorine dioxide in equipment corrosion}

To study equipment corrosion we monitored different metallic pieces (stainless steel; cans, bottle caps) for two weeks in different chlorine dioxide solutions: $0.5 \mathrm{mg} / \mathrm{l}, 0.75 \mathrm{mg} / \mathrm{l}, 1 \mathrm{mg} / \mathrm{l}, 2$ $\mathrm{mg} / \mathrm{l}$. Results were compared with clean water treatment.

Table 1. Impact of different chlorine dioxide solution concentration on corrosive equipment properties Tabela 1. Uticaj različitih koncentracija rastvora hlor-dioksida na korozivne osobine opreme

\begin{tabular}{|c|c|c|c|c|}
\hline $\mathrm{ClO}_{2}(\mathrm{mg} / \mathrm{l})$ & Cans & Can caps & Bottle caps & Stainless steel \\
\hline 0.5 & No corrosion & No corrosion & Corrosion trace & No corrosion \\
\hline 0.75 & No corrosion & No corrosion & Corrosion trace & No corrosion \\
\hline 1 & No corrosion & No corrosion & Moderately corroded & No corrosion \\
\hline 2 & No corrosion & No corrosion & Fully corroded & No corrosion \\
\hline $\mathrm{H}_{2} \mathrm{O}$ & No corrosion & No corrosion & Corrosion trace & No corrosion \\
\hline
\end{tabular}

Chlorine dioxide was corrosive only on bottle caps when concentration was more than $1 \mathrm{mg} / \mathrm{l}$.

\section{Laboratory and brewery ambient air control}

Mainly breweries micro flora consists on moulds, yeasts and bacteria. To test this sanitizing test were used $0.5 \mathrm{mg} / \mathrm{l}$ and $1 \mathrm{mg} / \mathrm{l}$ chlorine dioxide in the form of spray solution. Microbiologic situation was evaluated in MA and PCA. It was noticed that spraying in the air $1 \mathrm{mg} / \mathrm{l}$ chlorine dioxide minimizes significantly microbic rain in the ambient and also improve odors in the zone. To be more effective in this sanitizing procedure it is needed a study of air streams in the brewery.

\section{DISCUSSIONS}

Studying chlorine dioxide kinetics it is obvious that this disinfectant it is very effective when used for water and waste water treatment. It can be used also for water filtration and distribution system disinfection. Chlorine dioxide can be dosage in line at supply water system, also can periodically batch loaded into the waste water sewage or metered on a timed basis to control waste waters discharged from the brewery [7].

This disinfectant it is very important to be used during brewery equipment cleaning process. This implementation has been a subject of our research work and finally it is implemented in industrial scale where chlorine it is used as the final sanitizing rinse in CIP systems, typically can be applied at between 2 and $5 \mathrm{mg} / \mathrm{l}$. This concentration results also very effective in destroying detrimental wild and culture yeast strains [8].

Chlorine dioxide effectively controls biofilms found randomly on heat exchange surfaces, in pipes, lines, orifices and pumps. Chlorine dioxide is the best available technology for controlling biofilms in these systems.

Chlorine dioxide can be injected into lubrication streams for effective slime control on conveyor lines. Chains and conveyors run more smoothly, with less wear on chains and motors. Additionally, even small levels of chlorine dioxide will help to effectively deodorize the line.

Chlorine dioxide solutions can be sprayed on filler head assemblies in 10-second bursts during breaks and lunch. The spray coats all surfaces attacking biofilms, inhibiting bacterial growth and deodorizing the surrounding environment.

Misting of chlorine dioxide solutions into air streams prevents the spread of mould and wild yeast. This controls "off-tastes" in the 
product. Chlorine dioxide is also an excellent odor neutralizer, helping to control secondary and tertiary amines [9].

As we have mentioned above chlorine dioxide can be used in different applications inside the brewery in industrial scale. The main applications and the recommended concentrations are listed below:

1. Housekeeping and maintenance procedures in the brewery. Manual sanitizing processes. Concentrations used varied $1-2 \mathrm{mg} / \mathrm{l}$.

2. Final rinsing additive in CIP system. Concentrations used varied $2-5 \mathrm{mg} / \mathrm{l}$ in the function of cleaning program, equipment (fermentator, heat exchangers, filter unit, pipes, filling lines etc.), pollution degree etc.

3. Manual sanitizing agent at filling line heads in a concentration 2-3 $\mathrm{mg} / \mathrm{l}$.

4. Sanitizing agent of different packaging materials (cans, PET) instead of peracetic acid. Concentration used varied from $2-5 \mathrm{mg} / \mathrm{l}$.

5. Ambient odor and air quality control (especially at filling lines environment). Chlorine dioxide was sprayed in the air in a concentration 2 $\mathrm{mg} / \mathrm{l}$.

6. Supply water disinfection was done in concentration 1-2 mg/l.

7. Waste water treatment in concentration up to 5 $\mathrm{mg} / \mathrm{l}$.

8. Different housekeeping procedures, especially to control biofilms in conveyors, transport equipments etc. Dosage used 3-5 mg/l.

In some cases combine $\mathrm{Cl}_{2}$ and $\mathrm{ClO}_{2}$ is very effective, sometimes it is needed very small dosages comparing to one disinfectant.

\section{CONCLUSIONS}

The effectively of chlorine dioxide is at least as high as chlorines, though at lower concentrations. But there are more and important advantages related with its bactericidal efficiency, contact time, $\mathrm{pH}$ tolerance (4-10), better solubility, no distinct smell etc.

Equipment in a brewery are almost all stainless steel. There were noticed no corrosion phenomena's using chlorine dioxide concentration to $3 \mathrm{mg} / \mathrm{l}$.
This disinfectant can be used as a packaging material sanitizer instead of peracetic acid which it is not as effective as chlorine dioxide and has a higher cost. It is not recommended to use it at bottle caps sanitizing process because it is very corrosive for these materials.

Spraying in a concentration $0.5-1 \mathrm{mg} / \mathrm{l}$ dioxide chlorine solution result very effective on laboratory and brewery ambient control.

As a conclusion, chlorine dioxide can be used in a brewery as a universal disinfectant to control equipment cleaning process, water and waste water quality, packaging materials and air quality. These processes are cost effective and give better results comparing to conventional treatments used in the past.

\section{REFERENCES}

[1] CMA. Chemical Manufacturers Association (1989) A Review of the Uses, Chemistry, and Health Effects of Chlorine Dioxide and the Chlorite Ion. Washington, D.C.

[2] M.A.Bernarde, B.M.Israel, V.P.Olivieri, M. L.Grandstrom (1965) Efficiency of Chlorine Dioxide as a Bactericide, Appl. Microbiol, 13(5), 776-785

[3] Standard Testing Methods, Tech. Sect., CPPA, Montreal, Method No. J14P.

[4] European Brewing Chemists (1992) Analytica EBC; Methods of Analysis,

[5] Europian Brewing Chemists (1997) Analytica-EBC Microbiologica.

[6] M.A.Bernarde, W.B.Snow, V.P.Olivieri, B.Davidson (1967) Kinetics and Mechanism of Bacterial Disinfection by Chlorine Dioxide, Appl. Microbiol., 15(2), 257-264.

[7] M.Dufour, R.S.Simmonds, P.J.Bremer (2004) Development of a laboratory scale clean-in-place system to test the effectiveness of natural antimicrobials, Journal of Food Protection., 67(7), 1438-1443.

[8] L.Pinguli, I.Malollari. L.Lici (2017) Optimization of cleaning process in breweries an important tool in efficient use of water and minimization of discharges, http://www.idpublications.org/ejet-vol-5no-4-2017/

[9] E.Storgårds (2000) Process hygiene control in beer production and dispensing, Ph.D. thesis, VTT Technical Research Centre of Finland, Espoo, Finland. 


\section{IZVOD}

\section{PREDNOSTI KORIŠĆENJA HLOR-DIOKSIDA U INDUSTRIJI PIVA}

$U$ industriji piva je veoma važno osigurati higijenske uslove. Hlor-dioksid je multispektralno dezinfekciono sredstvo koje je moćnije, lakše za korišćenje i ekološki prihvatljivije od hlora. Upotreba hlor-dioksida pri proizvodnji piva ima puno prednosti jer se može koristiti na različitim mestima za različite namene. Hlor-dioksid može penetrirati, poremetiti i uništiti biofilm za koji je hlor potpuno neefikasan. Glavne aplikacije obuhvataju proces čišćenja u mestu (CIP) i saniranje postupka. Očigledno je da je hlor-dioksid veoma efikasan, posebno kada se koristi kao poslednje sredstvo za ispiranje u CIP sistemima.

Druga najvažnija primena je kontrola biofilmova pronađenih slučajno na površinama za razmenu toplote, u cevima, procesnim linijama, otvorima pumpi, transporterima, lancima itd. U obliku sprej rastvora može se koristiti kao sredstvo za ručno saniranje različitih površina, kao što su npr., sklopovi glave za punjenje tokom procesa punjenja.

Veoma važna primena je dezinfekcija linija filtracije vode i distribucije. Hlor-dioksid je vrlo efikasan kada se koristi za dezinfekciju vode, kako za piće, tako i u domaćinstvima. Posebno je važna kontrola higijene ambijenta, naročito u liniji za punjenje. Hlor-dioksid je, takođe, odličan neutralizator mirisa. Ovaj proces kontroliše "ukus" u finalnom proizvodu. Korišćenje hlor-dioksida je, takođe, vrlo efikasno za sanaciju i uklanjanje biofilmova sa unutrašnjih površina transportnih posuda. Da bi se postigli optimalni rezultati potrebna je pažljiva studija, jer je za svaku aplikaciju raspon koncentracije $i$ vreme kontakta različit. Sa druge strane, veoma je važno kontrolisati njegove korozivne osobine.

Ključne reči: hlor-dioksid, sredstvo za saniranje, biofilm, korozija.

Naučni rad

Rad primljen: 22. 09. 2018.

Rad prihvaćen: 19. 10. 2018.

Rad je dostupan na sajtu: www.idk.org.rs/casopis

(C) 2018 Authors. Published by Engineering Society for Corrosion. This article is an open access article distributed under the terms and conditions of the Creative Commons Attribution 4.0 International license (https://creativecommons.org/licenses/by/4.0/) 